\title{
Approaching the Golden Age of Natural Product Pharmaceuticals from Venom Libraries: An Overview of Toxins and Toxin-Derivatives Currently Involved in Therapeutic or Diagnostic Applications
}

\author{
Jay W. Fox ${ }^{1, *}$ and Solange M. T. Serrano ${ }^{2}$ \\ ${ }^{1}$ University of Virginia, Charlottesville, VA 22908-0734, USA and ${ }^{2}$ Laboratorio Especial de Toxinologia Aplicada/CAT-CEPID, Insti- \\ tuto Butantan, Sao Paulo, SP 05503-900, Brazil
}

\begin{abstract}
Poisons and the toxins found in venomous and poisonous organisms have been the focus of much research over the past 70 years, most of which has been directed at understanding the biochemical and physiological mechanisms by which they elicit their dramatic pathological consequences. Much knowledge has been gained in terms of how poisons and venoms and their composite toxins give rise to the syndromes associated with envenoming and poisoning and in some isolated cases there have been a few such agents promoted for therapeutic use. However, it has only been in the past decade that an explosion of interest has occurred in mining these natural, highly evolved libraries of bioactive toxins and poisons for use in pharmacotherapeutics as drugs or drug leads as well as in diagnostic applications. We ascribe this recent phenomenon to advances in toxinology which have provided investigators with a relatively thorough understanding of the nature of venoms and their biologically active toxins: particularly with regard to the peptidomes and proteomes of venoms. This is in conjunction with our greatly improved understanding of the etiology of many human diseases and the identification of sites of potential therapeutic intervention. In this review we provide an overview of some of the toxins, toxin derivatives or poisons from animal venoms and secretions which are in various stages of development for use as pharmaceuticals or diagnostics in human diseases. As one will recognize, developments in this field suggest that toxinology is now entering a golden age in terms of the identification and use of toxins as potent novel pharmaceuticals.
\end{abstract}

\section{INTRODUCTION}

The toxins found in venomous and poisonous animals have evolved over time to play a critical role in prey capture, immobilization and defense for these organisms. For millennia humans have held both a fascination and fear of the actions of venomous and poisonous animals and as such this has been an active area of research, scientific and otherwise since the time when humans made the correlation of illness or death associated with their interactions with venomous and poisonous animals.

As a point of reference one should understand that when the term "venomous" animal is used we are referring to animals which generate venom via a tissue or organ such as a venom gland. The venom is typically introduced into prey organisms via parenteral application with a specialized apparatus such as a fang or teeth or nematocytes. On the other hand, poisonous animals produce toxins in a similar manner via specialized cells or tissues or they may acquire toxins from the environment typically via their diets. Similarly, the toxins from poisonous animals must generally be ingested by predator organism for their toxic actions to occur. An exception being certain poisonous animals such as frogs which secrete their poisons from their skin which then cause irritation to the predator via contact or ingestion with the poisonous animal. There are both venomous and poisonous marine animals and land animals. Toxins and poisons from animals have been utilized as drugs and drug leads for treatment of human diseases and several of these will be discussed below.

Toxinology - The Study of Plant, Microbial and Animal Venoms, Poisons, and Toxins

As mentioned, humans have had a long-standing interest in toxins and poisons found in nature. Toxinology is the scientific field which investigates many aspects of venomous or poisonous organisms such as biological and chemical characterization of the toxins and poisons found in venomous and poisonous organisms. The main goal is to gain an understanding of how these poisons and

*Address correspondence to this author at the Department of Microbiology, University of Virginia, PO Box 800734, Charlottesville, VA 22908-0734, USA; Tel: 434-924-0050; E-mail: jwf8x@virginia.edu toxins function both alone and together in a venom or poisonous mixture to produce the symptomatology and pathologies associated with envenomation, contact or ingestion of the venoms or poisons respectively. Due to significant advances in the technologies which can now be brought to bear on the studies of venoms and poisons there have been tremendous increases in our understanding of the complexity composition of venoms and poisons. Over the past several years there have been numerous publications detailing the genomes, transcriptomes and proteomes of animal venoms [1-6]. From these studies we have substantially increased our level of characterization of the venoms as well as discovered new ways of looking at toxin evolution in venoms and how the evolution of venoms has led to the highly toxic organisms with which we find ourselves living [7].

\section{Animal Venoms and Poisons}

We will not attempt to provide an exhaustive review of the nature, composition and activities of animals venoms and poisons; this is outside the scope of this review. However, we will provide as appropriate to this review a very brief summary of some of the major venoms and poisons from animals from which therapeutic drugs have been developed or are under development.

\section{Terrestrial Animals}

\section{Snake Venoms}

The most well recognized venomous land animals are the venomous snakes which have highly developed glands for producing venom with variable apparatuses for delivering the venom into the prey. The composition and biological activities of snake venoms vary based on the family and often genus and species of snakes as well as their environments, diets and sex [8-9]. However, in general they contain some combination of peptides, enzymes and neurotoxins. In the peptide group are found activities such as proteinase inhibitors, integrin antagonists and cholinesterase inhibitors. The enzyme group includes phospholipases A2, amino acid oxidases and serine and metalloproteinases. Members of each group have been demonstrated to have toxic activities. In the case of neurotoxins a variety of functional classes has been identified. The presynaptic toxins include neurotoxic phospholipases A2 that block acetylcholine release from the synapse and toxins which block ion- 
channels such as dendrotoxins from mamba venoms and cause an increase in neurotransmitter from the endplate. L-amino acid oxidase from certain snake venoms has been demonstrated to cause cellular apoptosis [10]. The serine and metalloproteinases in snake venoms are generally attributed for the coagulopathies associate with snake envenoming [11-13]. In general a variety of symptoms is associated with snake envenoming and they are dependent on the type of snake and to a certain extent the prey. As mentioned there can be neurotoxic symptoms most typically found in envenomings by Elapidae snakes due to the presence of neurotoxic blockage of neuromuscular synapases to give rise to a paralysis often leading to respiratory failure. Coagulopathies associated with envenoming by vipers is common and is a result of a number of proteolytic and non-proteolytic toxins in these venoms which generally lead to incoagulability of the blood [11]. This, coupled with hemorrhage and edema also caused by proteinases present in viper and pit-viper venoms, often leads to cardiovascular shock. Many snake venoms also have phospholipases A2 which directly affect and destroy muscle tissue releasing myoglobulin which may lead to renal failure [14].

\section{Scorpion Venoms}

The venoms from scorpions are primarily composed of a complex mixture of peptide toxins. These peptides generally function as ion-channel toxins to give rise to a complex, synergistic neurotoxic effect due to numerous, specific ion-channel toxins present in the venoms [15].

\section{Amphibian Poisons}

Poisonous secretions have been identified in the secretions of a number of frogs, toads, newts and salamanders and contain amines, steroids, alkaloids and peptides [16]. The poisonous effects of the secretions are highly variable but can include neurotoxic effects, hallucinogenic effects, analgesia, vasoconstriction and seizures. The newt Taricha torosa and some species of toads have been reported to have high concentrations of the neurotoxin tetrodotoxin. It is believed that most of the toxins found in amphibian secretions are derived from food sources for these amphibians.

\section{Lizard Venoms}

Both the Gila monster and the Mexican beaded lizard (Heloderma suspectum and Heloderma horridum, respectively) are venomous and their venoms are primarily comprised of protein toxins. On envenomation by these lizards, the venom secreted from the glands mix with saliva and then via capillary action flows along the sides of the teeth and enters the wounds produced by the bite. Hyaluronidases, kallikreins and arginine ester hydrolases are some of the enzymes reported in the venom $[17,18]$.

\section{Mammalian Toxins}

In the saliva of the new world vampire bats (Desmodontidae) are potent anticoagulatant plasminogen activator enzymes that prevent clot formation and thus promote blood flow from the bite of these animals [19].

\section{Marine Animals \\ Cone Snail Venoms}

Cone snail venoms are comprised of protein and peptide toxins and these venoms have provided researchers one of the richest sources of reagents for investigating ion-channels. There are four major classes of toxins found in cone snail venoms: $\alpha$-conotoxins, $\varpi$-conotoxins; $\mu$-conotoxins and $\delta$-conotoxins [20]. Each class is characterized by a particular biological function. For example, the $\delta$-conotoxins act at neuromuscular synapses to block nerve transmission. The $\mu$-conotoxins block sodium channels of skeletal muscle. The $\delta$-conotoxins cause a hyperpolarization of sodium channels and the $\varpi$-conotoxins block calcium-channels.

\section{Marine Animals Containing Tetrodotoxin}

A variety of marine organisms have sequestered within their bodies the toxin tetrodotoxin [21]. Tetrodotoxin is a potent inhibitor of sodium channels that causes paralysis of predators which ingest the organisms such as is the case with the puffer fish, Fugu rubripes and other members of the family Tetraodontidae, or in the case of the blue-ringed octopuses, Hapalochlaena maculosa and $\mathrm{H}$. lunulata, where the toxin is present in the saliva of these animals and enters the prey when bitten by these octopi.

\section{Toxins or Toxin-Based Drugs Approved for Use in the USA}

As a starting point for this review we will discuss animal toxins and animal toxin-based compounds that have already received US Food and Drug Administration approval for use as drugs for treatment of specific indications. We do this not to presume a U.S.centric view of the drug/pharmaceutical world but simply recognized this as a readily documented reference for those toxins that are currently in use in the United States. Our approach is to outline the diseases and the toxins or their subsequent toxin structure based drugs that are currently approved by the U.S. FDA with consideration given to the venom or poison from which the toxins are derived (Table 1).

Table 1. Toxin-Based Drugs Approved for Use by the U.S. Food and Drug Administration

\begin{tabular}{|c|c|c|c|c|}
\hline Drug Name & Toxin/Origin & Indication & Mechanism of Action & FDA Website Links \\
\hline \multicolumn{5}{|c|}{ Disease: Hypertension } \\
\hline Captopril ${ }^{\circledR}$ & $\begin{array}{l}\text { Bradykinin-potentiating peptides } \\
\text { from Bothrops jararaca venom. }\end{array}$ & Treatment of hypertension. & $\begin{array}{l}\text { Inhibition of Angiotensin } \\
\text { Converting Enzyme. }\end{array}$ & $\begin{array}{l}\text { http://www.fda.gov/cder/foi/anda/97/7 } \\
\text { 4532ap.pdf }\end{array}$ \\
\hline \multicolumn{5}{|c|}{ Disease: Heart disease/Coagulopathies } \\
\hline $\begin{array}{l}\text { Aggrastat }{ }^{\circledR} \\
\text { (Tirofiban) }\end{array}$ & $\begin{array}{l}\text { Non-peptide structure based on } \\
\text { RGD sequence from snake } \\
\text { venom disintegrins }\end{array}$ & Treatment of angina. & $\begin{array}{l}\text { Reversible antagonist of the platelet } \\
\text { glycoprotein (GP) IIb/IIIa receptor; } \\
\text { inhibits platelet aggregation }\end{array}$ & $\begin{array}{l}\text { http://www.fda.gov/cder/foi/label/199 } \\
\text { 8/20912lbl.pdf }\end{array}$ \\
\hline $\begin{array}{l}\text { Integrilin }{ }^{\circledR} \\
\text { (Eptifibatide) }\end{array}$ & $\begin{array}{c}\text { Structure based on the KGD } \\
\text { sequence of disintegrin barbourin } \\
\text { from Sistrurus barbouri }\end{array}$ & Use in coronary angioplasty. & $\begin{array}{l}\text { Antagonist of the platelet receptor } \\
\text { glycoprotein (GP) IIb/IIIa of human } \\
\text { platelets; inhibits platelet aggregation }\end{array}$ & $\begin{array}{l}\text { http://www.fda.gov/cder/foi/nda/98/20 } \\
\text { 718_INTEGRILIN_pharmr_P1.pdf }\end{array}$ \\
\hline \multicolumn{5}{|c|}{ Disease: Chronic pain } \\
\hline $\begin{array}{c}\text { Prialt }{ }^{\circledR} \\
\text { (Ziconotide) }\end{array}$ & $\begin{array}{l}\omega \text {-conotoxin MVIIA from the } \\
\text { cone snail Conus magus }\end{array}$ & Treatment of severe chronic pain. & Block N-type Ca2+ channels. & $\begin{array}{c}\text { http://www.fda.gov/cder/foi/nda/2004/ } \\
\text { 21-060_Prialt_Pharmr.PDF }\end{array}$ \\
\hline \multicolumn{5}{|c|}{ Disease: Diabetes } \\
\hline $\begin{array}{l}\text { Byetta }^{\mathrm{TM}} \\
\text { (Exenatide) }\end{array}$ & $\begin{array}{l}\text { Exendin-4 ( } 39 \text { amino acid peptide) is } \\
\text { a incretin mimetic from the saliva of } \\
\text { the lizard Heloderma suspectum }\end{array}$ & $\begin{array}{l}\text { To improve blood sugar control in } \\
\text { adults with type } 2 \text { Diabetes Mellitus. }\end{array}$ & $\begin{array}{l}\text { Binding and activation of GLP-1 } \\
\text { receptor to reduce plasma glucose } \\
\text { and lower } \mathrm{HbA}_{1 \mathrm{c}} \text {. }\end{array}$ & $\begin{array}{c}\text { http://www.fda.gov/cder/foi/nda/2005/ } \\
\text { 021773_Byetta_pharmr.PDF }\end{array}$ \\
\hline
\end{tabular}




\section{Hypertension}

Hypertension, simply stated is when the blood pressure measurement exceeds 140/90 mmHg. Many physiological conditions can lead to high blood pressure and the long term effect of hypertension include heart failure, aneurysms, kidney failure, heart attacks, strokes and ruptures in the small blood vessels of the eyes contributing to blindness. Given that one of three Americans suffers from hypertension this is a potentially devastating disease. A number of treatments are available, simply beginning with healthier living habits to a plethora of drugs most of which function to relax vessel walls and thus decrease the blood pressure.

Snake venoms, particularly Viperidae venoms have long been known to be rich sources of peptides as well as proteins. In nature these peptide are thought to play a role in inhibiting the metalloproteinase activity in the venoms and crystal structures of snake venom metalloproteinases have been observed having peptides coordinated to the zinc in the active site of these proteinases [22, 23]. However, it was also clear that they may be important in the pathological effects of the venom as well. One of the typical symptoms of Viperidae envenoming is hypotension and shock [24]. In 1965 there appeared in the literature a report of a Bradykinin-potentiating factor (BPF) present in the venom of the South American snake Bothrops jararaca [25]. Bradykinin, a strong hypotensive agent that functions as a vasodilator, is derived by proteolytic processing of the plasma protein kininogen and the BPF from the venom appeared to function to potentiate the vasodilatory effects of bradykinin. It was later shown that these venom extracts could inhibit a zinc metalloproteinase termed angiotensin converting enzyme (ACE) which is responsible for the conversion of angiotensin I to the vasoconstrictor peptide angiotensin II in vivo [26, 27]. The venom factors responsible for the BPF activity/ACE inhibition were isolated by Ferreira and colleagues [28] and the sequence pGluLys-Trp-Ala-Pro was determined for one of the peptides and was synthesized and shown to have biological activity [29]. Independently Ondetti and colleagues also isolated several BPF peptides from B. jararaca which were demonstrated to inhibit ACE [30]. Ondetti, who was working at Squibb, New Brunswick, began collaborations with D. W. Cushman, who also was at Squibb working on ACE and the renin-angiotensin system. One of the nonapeptides isolated by this group, termed Teprotide, was used as a starting point for the development of a drug. Subsequently using these peptide structure/activity studies as a foundation an orally active ACE inhibitor termed Captopril was synthesized in 1975 [31]. Several generations of these drugs have been brought to market by Squibb and other pharmaceutical companies. Although these drugs are still in use there are a large number the alternative therapeutic choices available for treatment of hypotension. Nevertheless, the development of Captopril, clearly based on the research associated with the structure/function analysis of biologically active peptides in Viperidae venoms, represents one of the first "block buster" drugs stemming from a venom toxin.

\section{Heart Disease}

Two drugs based on snake venom toxin structures are in use as reversible antagonists of the platelet glycoprotein GPIIb/IIIa receptor which essentially functions to inhibit platelet aggregation and thereby play a therapeutic role in the treatment of angina and in coronary angioplasty as anti-platelet factors. Disintegrins are snake venom peptides ranging from 40-100 amino acid residues that possess 4 to 8 disulfide bonds. They were first described by Huang and colleagues [32] and were distinguished by the Arg-Gly-Asp motif which was demonstrated to be involved in binding to the GPIIb/IIIa integrin receptor on platelets to block aggregation. More recently, numerous other disintegrins have been isolated and characterized and many of these have been shown to bind to non-Arg-Gly-Asp receptors [33]. Tirofiban (Aggrastat ${ }^{\circledR}[N$ - (butylsulfonyl)-O-[4-(4piperidinyl)butyl]-L-tyrosine monohydrochloride monohydrate]) is a non-peptide drug based on the Arg-Gly-Asp sequence found in snake venom disintegrin proteins [34-36]. The other drug, Eptifi- batide (Integrilin $\left.{ }^{\circledR}\right)\left[\mathrm{N}^{6}-\left(\right.\right.$ aminoiminomethyl)- $\mathrm{N}^{2}$-(3-mercapto-1oxopropyl-L- lysylglycyl-L-a-aspartyl- L-tryptophyl-L -prolyl-Lcysteinamide, cyclic (1Ø6)-disulfide] is modeled on the biologically active Lys-Gly-Asp motif in the disintegrin barbourin from Sistrurus barbouri [37]. In the venom the disintegrins play a variety of roles in the symptomatology and pathology of envenomation by blocking platelet aggregation and thereby synergizing the effects of other toxins, such as the snake venom hemorrhagic metalloproteinases in the venom to produce bleeding and shock [38, 39]. They likely possess other important functions that play into the pathology by virtue of various disintegrin's abilities to bind to many different cell surface integrin receptors and modulate their signal transduction properties [40]. Given the specificity of these non-RGD containing disintegrins for non-RGD dependent integrins and the important roles these integrins play in a variety of biological processes one can imagine that these disintegrins are also under investigation and consideration for providing novel drug leads as did the RGDcontaining disintegrins for anti-platelet agents.

\section{Pain}

Ziconotide (Prialt $\left.{ }^{\circledR}\right)$ is the name given to a 25 -residue peptide toxin called $\varpi$-conotoxin MVIIA isolated from the cone snail $\mathrm{Co}$ nus magus [41]. Ziconotide is a selective, reversible blocker of neuronal $\mathrm{N}$-type voltage-sensitive calcium channels that produces potent antinociceptive effects by blocking neurotransmission from primary nociceptive afferents [42]. This drug and second generation non-peptide drugs are considered to be some of the best new drugs to treat chronic pain [43].

\section{Diabetes}

A very important discover was made when a 39 residue peptide termed exendin- 4 isolated from the venom/saliva of the lizard Heloderma suspectum was demonstrated to bind to the glucogonlike peptide- 1 receptor as an agonist and thereby decrease plasma glucose levels $[44,45]$. This has been developed into a drug called Byetta $^{\mathrm{TM}}$ which in addition to the above activities also lowers the levels of acetylated hemoglobin, $\mathrm{HbA}_{1 \mathrm{c}}$ making this a very useful drug for treating type 2 diabetes when used in conjunction with Glucophage $^{\circledR}$ (metformin), and/or a sulfonylurea like Amaryl ${ }^{\circledR}$ (glimepiride), Glucotrol ${ }^{\circledR}$ (glipizide), Micronase ${ }^{\circledR}$ (glyburide).

\section{Toxins or Toxin-Based Drugs Approved for Clinical Trial by the USA Food and Drug Administration}

Currently there are five toxins or toxin-based drugs undergoing clinical trials (Table 2). Three of these are directed at heart disease, specially heart attacks and strokes. Viperid venoms are well established for their ability to give rise to coagulopathy and thus one can readily expect that toxins in these venoms directly act on factors associated with blood coagulation. A variety of serine and metalloproteinase toxins from viperid venoms have been shown to be responsible for many of coagulopathies associated with viperid envenoming. The three venom-derived toxins for use in heart disease each have a different action in the blood. Alfimeprase is a recombinant form of the P-I metalloproteinase fibrolase isolated from the venom of Agkistrodon controtrix. [46, 47] which is a potential proteinase involved in fibrin clot dissolution. The clinical trials for the recombinant protein are focused on its use for treatment of occlusive arterial disease. Viprinex ${ }^{\mathrm{TM}}$ is the trademark name for the Ancrod, a 234 amino acid serine proteinase isolated from the venom of Agkistrodon rhodostoma [48]. Ancrod has long been in clinical applications in a variety of other countries as a defibrinogenating proteinase which specifically cleaves the fibrinogen A fibrinopeptides to give rise to fibrin monomers which cannot be stably crosslinked by factor XIIIa. Viprinex ${ }^{\mathrm{TM}}$ is also being tested as a defibrinogenating agent for use in the treatment of acute, ischemic stroke to attenuate or block additional clot formation in this disease. The saliva of vampire bats has long been known to contribute to non-coagulating blood at the site of the bite to promote a steady blood flow for the feeding bat. Desmoteplase is the name given to a plasminogen activator isolated from the saliva of the vampire bat 
Table 2. Toxin-Based Drugs Approved for Clinical Trials in the USA

\begin{tabular}{|c|c|c|c|c|}
\hline Drug Name & Toxin/Origin & Indication & Clinical Trial Name & Clinical Trial Phase/link \\
\hline Alfimeprase & $\begin{array}{l}\text { Recombinant analog of fibrolase, a } \\
\text { P-I snake venom metalloproteinase } \\
\text { from Agkistrodon contortrix }\end{array}$ & $\begin{array}{c}\text { To treat arterial } \\
\text { occlusive diseases }\end{array}$ & $\begin{array}{l}\text { Study of the ability of Alfimeprase to rapidly } \\
\text { dissolve blood clots in the leg and help prevent } \\
\text { the need for surgery on leg arteries }\end{array}$ & $\begin{array}{c}\text { Phase III/ } \\
\text { http://www.clinicaltrials.gov/ct/show/ } \\
\text { NCT00115999?order=1 }\end{array}$ \\
\hline Viprinex $^{\mathrm{TM}}$ & $\begin{array}{l}\text { Ancrod: Serine proteinase from } \\
\text { Agkistrodon rhodostoma }\end{array}$ & Defibrinogenating agent. & $\begin{array}{l}\left.\text { Ancrod (Viprinex }{ }^{\mathrm{TM}}\right) \text { for the treatment } \\
\text { of acute, ischemic stroke }\end{array}$ & $\begin{array}{c}\text { Phase III/ } \\
\text { http://www.clinicaltrials.gov/ct/show/ } \\
\text { NCT00141011?order=1 }\end{array}$ \\
\hline Desmoteplase & $\begin{array}{c}\text { Plasminogen activator from the } \\
\text { saliva of the vampire bat } \\
\text { Desmodus rotundus }\end{array}$ & For acute ischemic stroke & $\begin{array}{l}\text { Study of Desmoteplase (International } \\
\text { Nonproprietary Name [INN]) in acute } \\
\text { ischemic stroke (DIAS-2) }\end{array}$ & $\begin{array}{c}\text { Phase III/ } \\
\text { http://www.clinicaltrials.gov/ct/show/ } \\
\text { NCT00111852?order }=1\end{array}$ \\
\hline $\begin{array}{c}\text { Cilengitide } \\
(\text { EMD 121974) }\end{array}$ & $\begin{array}{l}\text { Cyclic Arg-Gly-Asp peptide. } \\
\text { Inhibitor of alpha-v integrins. }\end{array}$ & $\begin{array}{c}\text { To contain the growth and } \\
\text { spread ot tumor cells. }\end{array}$ & $\begin{array}{l}\text { Cilengitide in treating patients who are } \\
\text { undergoing surgery for recurrent or } \\
\text { progressive glioblastoma multiforme }\end{array}$ & $\begin{array}{c}\text { Phase II/ } \\
\text { http://www.clinicaltrials.gov/ct/show/ } \\
\text { NCT00112866?order }=1\end{array}$ \\
\hline $\begin{array}{l}\text { Chlorotoxin } \\
(131 \mathrm{I}-\mathrm{TM}-601)\end{array}$ & $\begin{array}{l}\text { Chloride channel blocker from } \\
\text { scorpion Leiurus quinquestriatus }\end{array}$ & $\begin{array}{c}\text { Targeting of } \\
\text { malignant glioma }\end{array}$ & $\begin{array}{l}\text { Binding to a protein complex on the surface } \\
\text { of glioma cells containing several proteins } \\
\text { implicated in glioma cell invasion }\end{array}$ & $\begin{array}{c}\text { Phase II/ } \\
\text { http://www.clinicaltrials.gov/ct/show/ } \\
\text { NCT00114309 }\end{array}$ \\
\hline
\end{tabular}

Desmodus rotundus [49]. Desmoteplase is being used in clinical trials to treat acute ischemic stroke, again with the aim of attenuating or blocking additional clot formation in these patients.

Great hopes have been placed on identifying novel agents for cancer therapy based on toxins present in venoms. As was the case in the discovery of the disintegrins being potent blockers of integrins and their use in the development of antiplatelet coagulatants, similar thinking was applied to cancer therapeutics since integrins play an important role in nearly all stages of cancer development [50]. Cilengitide (Table 2) is a cyclic peptide containing the ArgGly-Asp motif which functions as an inhibitor of $\alpha_{\mathrm{v}}$ integrins to attenuate or block tumor vascularization thereby functioning as an anti-angiogenic agent [51]. Clinical trials are underway for its use in the treatment of glioblastoma multiforme as well as several other forms of cancer.

Great hopes have been placed on identifying novel agents for cancer therapy based on toxins present in venoms. One agent which has been placed in clinical trial is a modified toxin isolated from the venom of the scorpion Leiurus quinquestriatus. Chlorotoxin (Table 2) is a small basic 36 amino acid peptide chloride channel blocker that was found by specific, directed screening to bind to the surface of glioma cells via an interaction with a cell surface complex of matrix metalloproteinase-2, and MT1-MMP [52-54]. The exact mechanism by which this toxin acts as an anti-invasive is somewhat unclear but presumably its interaction with MMP-2 is relevant. For use in clinical trials as a therapeutic against malignant glioma cancer, chlorotoxin has been covalently modified to incorporate $\mathrm{I}^{131}$. The drug, termed 131I-TM-601, takes advantage of the targeting of malignant glioma cells by the chlorotoxin to deliver the radioactive iodine isotope $\mathrm{I}^{131}$ which then destroys the cell by ionizing radiation. Regardless of the ultimate efficacy of 131I-TM-601, this serves as a useful example of drug design based on the highly specific activity of toxins, in this case to target specific chloride channels on malignant glioma cells, to deliver a cytotoxic agent at the site of the lesion.

\section{Toxins and Toxin-Based Drugs in Use in Other Countries and/or Under Development}

It is promising to note that there are numerous toxins and toxinbased drugs currently in use outside the U.S.A. or are being developed for trials both in and outside the U.S. (Table 3). A variety of novel snake venom toxins are currently being tested for use in treating coagulapathies and heart disease. Defibrase ${ }^{\circledR}$ is the trade name given to batroxobin, a serine proteinase isolated from the venom of

Table 3. Toxin-Based Drugs Approved for Use in other Countries or Under Development

\begin{tabular}{|c|c|c|c|c|}
\hline Drug Name & Toxin/Origin & Indication & Mechanism of Action & Additional Information \\
\hline Defibrase ${ }^{\circledR}$ & $\begin{array}{l}\text { Batroxobin: serine proteinase } \\
\text { from Bothrops atox moojeni }\end{array}$ & $\begin{array}{l}\text { Acute cerebral infarction; } \\
\text { unspecific angina } \\
\text { pectoris;sudden deafness. }\end{array}$ & $\begin{array}{l}\text { Batroxobin converts fibrinogen to } \\
\text { fibrin through the release of } \\
\text { fibrinopeptide A from fibrinogen. }\end{array}$ & http://www.pentapharm.com/sw255.asp \\
\hline Haemocoagulase ${ }^{\circledR}$ & $\begin{array}{l}\text { Two enzymes from Bothrops } \\
\text { atrox venom acting on } \\
\text { blood coagulation. }\end{array}$ & $\begin{array}{l}\text { Prevention and treatment } \\
\text { of hemorrhage. }\end{array}$ & $\begin{array}{l}\text { One enzyme has a thrombin } \\
\text { like effect, the other has a } \\
\text { thromboplastin like activity. }\end{array}$ & $\begin{array}{c}\text { http://www.pentapharm.com/sw250.asp } \\
\text { http://www.bio-genex.com/frames/pdf/hae.pdf - } \\
\text { search='Haemocoagulase' }\end{array}$ \\
\hline $\begin{array}{c}\text { Exanta }{ }^{\circledR} \\
\text { (Ximelagatran) }\end{array}$ & $\begin{array}{l}\text { Peptide isolated from the } \\
\text { venom of the cobra. }\end{array}$ & Oral anticoagulant. & Thrombin inhibition. & $\begin{array}{l}\text { http://intmedweb.wfubmc.edu/grand_rounds/2003/ximel } \\
\text { agatrandoc.html } \\
\text { http://www.astrazeneca.com/pressrelease/2283.aspx }\end{array}$ \\
\hline ABT-594 & $\begin{array}{c}\text { Based on the structure } \\
\text { of epibatidine } \\
\text { from frog Epipedobates tricolor }\end{array}$ & Analgesic. & $\begin{array}{l}\text { Agonist of nicotinic } \\
\text { acetylcholine receptor. }\end{array}$ & $\begin{array}{c}\text { http://www.abdn.ac.uk/chemistry/abt/ } \\
\text { http://www.ch.ic.ac.uk/local/projects/pan/page5.html }\end{array}$ \\
\hline Contulakin-G & $\begin{array}{l}\text { Glycopeptide from cone snail } \\
\text { Conus geograph }\end{array}$ & Analgesic. & Neurotensin receptors agonist. & $\begin{array}{l}\text { http://www.fda.gov/orphan/designat/alldes.rtf } \\
\text { http://www.patentalert.com/docs/000/z00052856.shtml }\end{array}$ \\
\hline $\begin{array}{l}\text { Tectin }^{\mathrm{TM}} \\
\text { Tetrodin }^{\mathrm{TM}} \\
\text { Tocudin }^{\mathrm{TM}}\end{array}$ & Tetrodotoxin from fish. & $\begin{array}{l}\text { Analgesia; Detoxification; } \\
\text { Anaesthesia }\end{array}$ & $\begin{array}{l}\text { Neurotoxin, which blocks action } \\
\text { potentials in nerves by binding to the } \\
\text { pores of the voltage-gated sodium } \\
\text { channels in nerve cell membranes. }\end{array}$ & $\begin{array}{l}\text { http://vm.cfsan.fda.gov/ mow/tet.html } \\
\text { http://www.wextech.ca/products/index.htm }\end{array}$ \\
\hline
\end{tabular}


Bothrops atrox moojeni which functions as an anti-coagulant by specific cleavage of fibrinogen A fibrinopeptides. The use of this proteinase is indicated for acute cerebral infarction, unspecific angina pectoris and sudden deafness to prevent further clot formation via rapid, long lasting reduction of plasma fibrinogen levels.

Exanta ${ }^{\circledR}$, also known as Ximelagatran, is a low molecular weight pro-drug peptide mimetic which is converted to melagatran which in turn functions via a different approach to attenuating the coagulation pathway by acting as a direct competitive inhibitor of thrombin to prevent cleavage of fibrinogen and subsequent fibrin clot formation [55]. Melagatran is a dipeptide mimetic based on a peptide structure isolated from cobra venom with a sequence that mimics the site preceding the thrombin cleavage site in the $A \alpha-$ chain of the fibrinogen molecule. Thus it functions as a direct, rapid, competitive, potent, selective and reversible inhibitor of human $\alpha$-thrombin.

Haemocoagulase ${ }^{\circledR}$ is the name given to a mixture of two proteinases isolated from the venom of Bothrops atrox which function in concert to promote clot formation. One enzyme promotes the conversion of prothrombin to thrombin (thromboplastin like enzymes). The other enzyme is a fibrinogenase which causes a direct conversion of fibrinogen to des-A-fibrin monomer which can be converted by thrombin into a fibrin clot. This mixture of venom toxins is indicated for the prevention or treatment of hemorrhage such as might be encountered in surgeries or as might occur following radiotherapy, bleeding diathesis in liver disorders, and capillary hemorrhages.

There are several toxins or toxin-based drugs on the market or in other countries or under development for analgesia. Contulakin$\mathrm{G}$ is a 16 amino acid residue O-glycosylated peptide isolated from the cone snail Conus geographus [56]. The peptide binds to human neurotensin type I receptors acting as an agonist of the 13-residue neurotensin, a neurotransmitter which produces long-lasting analgesia and can potentiate the actions of sedatives. This toxin is indicated as an anti-seizure, anti-inflammatory, anti-shock, analgesic drug among others. ABT-594 is the name given to a drug developed by Abbot Laboratories based on a structure similar to epibatidine, a potent analgesic nicotinic agonist alkaloid toxin isolated from an extract of the skin of the Ecuadorian frog, Epipedobates tricolor [57]. Epibatidine functions as a highly potent antinociceptive, but was found to be too toxic for use in humans. ABT-594 is of particular interest in that it is more potent than morphine but lacks morphine-associated side effects and only mild cardiovascular side effects [58]. Tetrodotoxin (TTX) is a well-known neurotoxin found in a variety of animals resulting from ingestion of the toxin from bacteria or dinoflagelates [59]. It is a heterocyclic, small, organic molecule that acts directly on the electrically active sodium channel in nerve tissue to block diffusion of sodium through the sodium channel thereby preventing depolarization and propagation of ac- tion potentials in nerve cells. A variety of formulations of tetrodotoxin (Table 3) have been produced for potential use as an analgesic and a local or topical anesthetic or for use in drug withdrawn such as treatment for heroin and other opiate addictions such as morphine, opium and methadone.

Given the highly toxic nature of venoms there has long been speculation that toxins or toxin-based structures could play a role in cancer therapeutics. The role of the cell surface receptors, the integrins, in cancer initiation, progression, invasion and metastasis is well appreciated and numerous integrins have been the focus of potential sites to interdict or attenuate these process [60]. With the advent of the discover of the snake venom disintegrins and characterization of their structural and functional properties coupled with an increased understanding of the role of integrins in carcinogenesis numerous studies directed towards identifying appropriate disintegrins and their integrin receptors have been undertaken. The most thoroughly studied of these is the disintegrin contortrostatin and $\beta 1$ integrins. Contortrostatin is a $13.5 \mathrm{kDa}$ dimeric disintegrin isolated from the venom of Agkistrodon contortix with each monomer having the Arg-Gly-Asp integrin binding motif [61]. This disintegrin was initially demonstrated to inhibit agonist stimulated platelet aggregation by binding to the platelet integrin $\alpha 2 b \beta 3$ (GPIIb/IIIa). Interestingly, in contrast with a single chain Arg-Gly-Asp containing disintegrin, multisquamatin, contortrostatin was shown capable of activating intracellular signaling pathways giving rise to tyrosine phosphorylation [62]. Using animal models of cancer contortrostatin has been demonstrated to block experimental metastasis of melanoma and limit breast cancer progression [63]. Contortrostatin is currently under development for entering clinical trials (Table $\mathbf{3}$ ).

\section{Toxins in use as diagnostic tool}

Four Viperid snake venom enzymes are currently in use as diagnostic tools (Table 4). Not surprisingly, given the coagulopathies associated with envenoming by Viperid snakes these enzymes are generally utilized in studies associated with blood components [64]. Reptilase ${ }^{\circledR}$ (batroxobin) a thrombin-like serine proteinase fibrinogenase isolated from the venom of Bothrops atrox was described early as being in development as for use in cerebral infarction (Table 3). It is also used to assess blood fibrinogen and fibrinogen degradation products [65]. Protac ${ }^{\circledR}$ is also a serine proteinase from Agkistrodon contortix venom which activates plasma protein $\mathrm{C}$ and thus is used in the determination of protein $\mathrm{C}$ and protein $\mathrm{S}$ levels in blood [66]. Botrocetin ${ }^{\circledR}$ is a platelet aggregating protein from the venom of Bothrops jararaca and functions by enhancing the affinity the von Willebrand Factor A1 domain for the platelet receptor GPIb $\alpha[23,67]$. The serine proteinase RVV-V from Vipera russelli venom is an activator of factor $\mathrm{V}$. Activated factor $\mathrm{V}$ is not stable and thus RVV-V can be used to selectively inactivate factor $\mathrm{V}$ in plasma and thereby serve in the determination of factor $\mathrm{V}$ levels [68]. RVV-X is a P-IV metalloproteinase also from $V$. russelli that

Table 4. Toxins Used as Diagnostic Tools

\begin{tabular}{|c|c|c|c|}
\hline Name & Toxin/Origin & Mechanism of Action & Use \\
\hline \hline $\begin{array}{c}\text { Reptilase }{ }^{\circledR}- \\
\text { Reagent }\end{array}$ & $\begin{array}{c}\text { Batroxobin: serine proteinase } \\
\text { from Bothrops }\end{array}$ & $\begin{array}{c}\text { Batroxobin converts fibrinogen to fibrin through } \\
\text { the exclusive release of fibrinopeptide } \\
\text { A from fibrinogen. }\end{array}$ & $\begin{array}{c}\text { Useful for studying the conversion of fibrinogen to fibrin. } \\
\text { It is particularly useful for the assessment of fibrinogen } \\
\text { degradation products and hypofibrinogenemias. }\end{array}$ \\
\hline Protac ${ }^{8}$ & $\begin{array}{c}\text { Serine proteinase from } \\
\text { Agkistrodon contortix venom }\end{array}$ & Direct protein C plasma activation. & Determination of protein C and protein S levels. \\
\hline Botrocetin ${ }^{\circledR}$ & $\begin{array}{c}\text { Platelet-aggregating protein from } \\
\text { Bothrops jararaca } \text { (and other Bothrops) }\end{array}$ & $\begin{array}{c}\text { It enhances the affinity of vWF A1 domain } \\
\text { for the platelet receptor GPIbo. }\end{array}$ & $\begin{array}{c}\text { Botrocetin may be used for the assay of vWF in plasma. } \\
\text { Aggregates formalin-fixed platelets. }\end{array}$ \\
\hline RVV-V & $\begin{array}{c}\text { RVV-V: Serine proteinase from } \\
\text { Vipera russelli venom. }\end{array}$ & $\begin{array}{c}\text { Proteolytic activation of factor V. } \\
\text { factor V in plasma and thus prepare a routine reagent } \\
\text { for factor V determination. }\end{array}$ & $\begin{array}{c}\text { RVV-X is used in diagnostic procedures to quantitatively } \\
\text { convert the zymogen factor X into factor Xa. }\end{array}$ \\
\hline RVV-X & $\begin{array}{c}\text { RVV-X: a P-IV metalloproteinase } \\
\text { from Vipera russelli venom. }\end{array}$ & Proteolytic activation of factor X. & \\
\hline
\end{tabular}


is a proteolytic activator of factor $\mathrm{X}$ and is used in diagnostics to quantitatively convert pro-factor $\mathrm{X}$ into factor $\mathrm{Xa}[69,70]$.

\section{Summary and Future Directions}

We have attempted in this brief overview to provide the reader with a sense of the profound effect that toxinology has had on clinical therapeutics. Specifically, we have outlined the toxins and toxin structure based drugs that are clinically in use, in clinical trials, or are being developed for eventual use as a therapeutic. In addition, we have shown that a number of toxins have important applications as research and diagnostic tools closely associated with clinical applications. Thus, we hope the reader has gained an appreciation of the field and how the years of research that went into various areas of toxinology have not only provided us with a much clearer understanding of the biomolecular and physiological basis for the pathologies associated with envenoming and poisoning by animals, but also that very pragmatic, functional outcomes have come from this research in terms of an enhanced pharmacopoeia to treat a variety of illnesses. The question now is what is next? Are there still drugs to be developed from animal venoms and poisons? Is the study of animal venoms and poisons relevant in the age of big pharma with massive chemical libraries ready for the development of new drugs once a target is identified? The answer is "possibly". The typical drug costs approximately $\$ 1.3$ billion dollars to bring to market and thus the demand for "block buster" drugs in large pharmaceutical companies. This has given rise to the approach of rapidly screen large chemical libraries available in most pharmaceutical companies once a biological target is identified for finding drug leads. The advantages here are the size and quality of the libraries and the speed by which they can be assayed. Although one can consider venoms as natural libraries of bioactive molecules they are more difficult to work with compared to the chemical libraries due to their liability and the wide range of concentrations of the biologically active substances in the venom. Thus, screening such a nature library may lead to false negative results due to low concentrations of the molecules of interest. In that sense such an approach with venoms may not be the best for identifying drug leads.

There is occurring an incredible advance in understanding venoms at the genomic, transcriptomic and proteomic levels and therefore we will soon have a rather complete biomolecular assessment of many types of venom. In these cases, knowledge of these structures and the identification of new structures may provide relevant "leads" for use against appropriate drug targets. Also, one must not lose sight that many novel discoveries in molecular biology were made with the use of toxins for which at the time the "target" was not known. The use of toxins in ion-channel discoveries and the acetylcholine receptor are two of the most well known [71.72]. Similarly, as we increase our knowledge of the structural basis for toxin activities, structures that have evolved to a highly defined function, this may be harnessed for use in drug design. For example using a toxin structure as a "scaffold" and modified for a particular binding function has been successfully developed as a CD4 mimic that can inhibit HIV-1 entry into cells [73, 74].

In summary, the years of toxinological research are now being to be translated into meaningful, practical applications as evidenced by toxins and toxin structure based drugs in clinical use and in development pipelines. We would anticipate this to continue into the near future and perhaps even accelerate as we approach a more complete understand of animal venoms, poisons and their biological activities.

\section{REFERENCES}

[1] Serrano SMT, Shannon JD, Wang D, Camargo AC, Fox JW. A multifaceted analysis of Viperid snake venoms by two-dimensional electrophoresis: An approach to understanding venom proteomics. Proteomics 2005; 5: 501-10.

[2] Gallagher PG, Bao Y, Serrano SMT, Laing GD, Theakston RDG, Gutierrez JM, et al. Role of the snake venom toxin jararhagin in proinflammatory pathogenesis: In vitro and in vivo gene expression analysis of the effects of the toxin. Arch Biochem Biophys 2005; 441(1): $1-15$

[3] Magalhaes GS, Junqueira-de-Azevedo IL, Lopes-Ferreira M, Lorenzini DM, Ho PL, Moura-da-Silva AM. Transcriptome analysis of expressed sequence tags from the venom glands of the fish Thalassophryne nattereri. Biochimie 2006; 88: 693-9.

[4] Junqueira-de-Azevedo ILM, Ho PL. A survey of gene expression and diversity in the venom glands of the pitviper snake Bothrops insularis through the generation of expressed sequence tags (ESTs). Gene 2002; 299: 279-91.

[5] Francischetti IMB, My-Pham V, Harrison J, Garfield MK, Ribeiro JMC. Bitis gabonica (Gaboon viper) snake venom gland: toward a catalog for the full-length transcripts (cDNA) and proteins. Gene 2004; 337: 55-9.

[6] Fox JW, Ma L, Nelson K, Sherman N, Serrano SMT. Comparison of indirect and direct approaches using ion-trap and fourier transform ion current resonance mass spectrometry for exploring viperid venom proteomics. Toxicon 2006; 47: 700-14.

[7] Fry BG. From genome to "venome": Molecular origin and evolution of the snake venom proteome inferred from the phylogenetic analysis of toxin sequences and related body proteins. Genome Res 2005; 15: 403-20.

[8] Menezes MC, Furtado MF, Travaglia-Cardoso SR, Camargo AC, Serrano SMT. Sex-based individual variation of snake venom proteome among eighteen Bothrops jararaca siblings. Toxicon 2006; 47(3): 304-12.

[9] Fox JW, Shannon JD, Stefansson B, Kamiguti AS, Theakston RDG, Serrano SMT, et al. In: Menez A Ed, Perspectives in toxinology. United Kingdom, John Wiley \& Sons Inc 2002; 97-106.

[10] Torii S, Yamane K, Mashima T, Haga N, Yamamoto K, Fox JW, et $a l$. Molecular cloning and functional analysis of apoxin I, a snake venom-derived apoptosis-inducing factor with L-amino acid oxidase activity. Biochemistry 2000; 39: 3197-205.

[11] White J. Snake venoms and coagulopathy. Toxicon 2005; 45: 95167.

[12] Serrano SMT, Maroun RC. Snake venom serine proteinases: sequence homology vs. substrate specificity, a paradox to be solved. Toxicon 2005; 45: 1115-32.

[13] Fox JW, Serrano SMT. Structural considerations of the snake venom metalloproteinases, key members of the M12 reprolysin family of metalloproteinases. Toxicon 2005; 45: 969-85.

[14] Danse JM, Gasparini S, Menez A. In: Kini RM, Ed, Venom phospholipase $\mathrm{A}_{2}$ enzyme: structure, function and mechanism. United Kingdom, Wiley 1997; 29-71.

[15] Rodriguez de la Vega RC, Possani LD. Overview of scorpion toxins specfic for $\mathrm{Na}+$ channels and related peptides: biodiversity, structure-function relationships and evolution. Toxicon 2005; 46: 831-44.

[16] Daly JW, Myers CW, Whittaker N Further classification of skin alkaloids from neotropical poison frogs (Dendrobatidae), with a general survey of toxic/noxious substances in the amphibia. Toxicon 1987, 25:1023-95.

[17] Russell FE, Bogert CM. Gila monster: its biology, venom and bite a review. Toxicon 1981; 19: 341-59.

[18] Bonnet MS. The toxicology of Heloderma suspectum: the Gila monster. British Homeopath J 2000; 89: 198-204.

[19] Schleuning WD. Vampire bat plasminogen activator DSPA-alpha-1 (desmoteplase): a thrombolytic drug optimized by natural selection. Haemostasis 2001; 31(3-6): 118-22.

[20] Terlau H, Olivera BM. Conus venoms: a rich source of novel ion channel-targeted peptides. Physiol Rev 2004; 84: 41-68.

[21] Daly JW, Myers CW, Whittaker N. Further classification of skin alkaloids from neotropical poison frogs (Dendrobatidae), with a general survey of toxic/noxious substances in the amphibia. Toxicon 1987, 25(10): 1023-95.

[22] Robeva A, Politi V, Shannon JD, Bjarnason JB, Fox JW. Synthetic and endogenous inhibitors of snake venom metalloproteinases. Biomed Biophys Acta 1991; 50: 769-73.

[23] Zhang D, Botos I, Gomis-Rüth F-X, Doll R, Blood C, Njoroge G, et al. Structural interaction of natural and synthetic inhibitors with the matrix metalloproteinase, Atrolysin C (Ht-d), Proc Natl Acad Sci USA 1994; 91: 88447-51. 
[24] Marsh N, Whaler B. The effects of snake venoms on the cardiovascular and haemostatic mechanisms. Int. J. Biochem 1978; 9: 21720 .

[25] Ferreira SH. A bradykinin-potentiating factor (BPF) present in the venom of Bothrops jararaca. Br J Pharmacol 1965; 34: 163-69.

[26] $\mathrm{Ng} \mathrm{KKF}$, Vane JR. Some properties of angiotensin converting enzyme in the lung in vivo. Nature 1970; 225: 1142-4.

[27] Hayashi MA, Camargo AC. The Bradykinin-potentiating peptides from venom gland and brain of Bothrops jararaca contain highly site specific inhibitors of the somatic angiotensin-converting enzyme. Toxicon 2005; 45:1163-70.

[28] Ferreira SH, Bartelt DC, Green LJ. Isolation of bradykininpotentiating peptides from Bothrops jararaca venom. Biochemistry 1970; 9: 2583-93.

[29] Stewart JM, Ferreira SH, Greene LJ. Bradykinin potentiating peptide PCA-Lys-Trp-Ala-Pro. An inhibitor of the pulmonary inactivation of bradykinin and conversion of angiotensin I to II. Biochem Pharmacol 1971; 20: 1557-67.

[30] Ondetti MA, Williams NM, Sabo EF, Pluscec J, Weaver ER, Kocy O. Angiotensin-coverting enzyme inhibitors from the venom of Bothrops jararaca: Isolation, elucidation of structure and synthesis. Biochemistry 1971; 10: 4033-39.

[31] Smith CG, Vane JR. The discovery of captopril. FASEB J 2003; 17: 788-9.

[32] Huang TF, Holt JC, Lukasiewicz H, Niewiarowski S, Trigramin. A low molecular weight peptide inhibiting fibrinogen interaction with platelet receptors expressed on glycoprotein IIB-IIIa complex. J. Biol. Chem 1987; 262: 16157-63.

[33] Calvete JJ, Marcinkiewicz C, Monleon D, Esteve V, Celda B, Juarez $\mathrm{P}$, et al. Snake venom disintegrins: evolution of structure and function. Toxicon 2005; 45: 1063-74.

[34] Egbertson MS, Chang CT, Duggan ME, Gould RJ, Halczenko W, Hartman GD, et al. Non-peptide fibrinogen receptor antagonists. 2. Optimization of a tyrosine template as a mimic for Arg-Gly-Asp. J Med Chem 1994; 37: 2537-51.

[35] Barrett JS, Murphy G, Peerlinck K, De Lepeleire I, Gould RJ, Panebianco D, et al. Pharmacokinetics and pharmadynamics of MK-383, a selective non-peptide platelet glycoprotein-1lb/lla receptor antagonist, in healthy men. Clin Pharmacol Ther 1994; 56: $377-$ 88.

[36] Topol EJ, Byzova TV, Plow EF. Platelet GPIIb-IIIa blockers. Lancet 1999; 353: 227-31.

[37] Scarborough RM, Naughton MA, Teng W, Rose JW, Phillips DR, Nannizzi L, et al. Design of potent and specific integrin antagonists. Peptide antagonists with high specificity for glycoprotein IIbIIIa. J Biol Chem 1993; 268: 1066-73.

[38] Phillips DR, Scarborough RM. Clinical pharmacology of eptifibatide. Am J Cardiol 1997; 80: 11B-20B.

[39] Fox JW, Bjarnason JB. In: Barrett AJ Ed, Methods in enzymology proteolytic enzymes. Academic Press 1995; 369-87.

[40] Marcinkiewcz C. Functional characteristic of snake venom disintegrins: potential therapeutic implication. Curr Pharm Des 2005; 11(7): 815-27

[41] Olivera BM, Rivier J, Scott JK, Hillyard DR, Cruz LJ. Conotoxins. J Biol Chem 1991; 266: 22067-70.

[42] Bowersox SS, Luther R. Pharmacotherapeutic potential of omegaconcotoxin MVIIA (SNX-111), an N-type neuronal calcium channel blocker found in the venom of Conus magus. Toxicon 1998; 36:1651-58.

[43] Garber K. Peptide leads new class of chronic pain drugs. Nat Biotech 2005; 23: 399.

[44] Eng J, Kleinman WA, Sing L, Singh G, Raufman JP. Isolation and characterization of exendin-4, an exendin-3 analogue, from Heloderma suspectum venom. J Biol Chem 1992; 267:7402-05.

[45] Young A, Gedulin BR, Bhavsar S, Bodkin N, Jodka C, Hansen B, et al. Glucose-lowering and insulin-sensitizing actions of exendin4. Diabetes 1999; 48:1026-34.

[46] Toombs CF. Alfimeprase: pharmacology of a novel fibrinolytic metalloproteinase for thrombolysis. Haemostasis 2001 31:141-7.

[47] Esnouf MP, Tunnah GW. The isolation and properties of the thrombin-like activity from Agkistrodon rhodostoma venom. Br J Haematol 1967;13: 581-86.
[48] Iqbal O, Aziz S, Hoppensteadt DA, Ahmad S, Walenga JM, Bakhos M, et al. Emerging anticoagulant and thrombolytic drugs. Expert Opin Emerg Drugs 2001; 6: 111-35

[49] Gardell SJ, Duong LT, Diehl RE, York JD, Hare TR, Register RB et al. Isolation, characterization and cDNA cloning of a vampire bat salivary plasminogen activator. J Biol Chem 1989; 64: 1794752

[50] Tucker GC. Integrins: molecular targets in cancer therapy. Curr Oncol Rep 2006; 8:96-103.

[51] Colevas AD, Scharf O, Schoenfeldt M. Clinical trial referral resource. Current clinical trials of cilengitide, an alpha(v) antagonist in clinical development as an anticancer agent. Oncology 2004; 18: 1778-2.

[52] DeBin JA, Maggio JE, Strichartz GR. Purification and characterization of chlorotoxin, a choloride channel ligand from the venom of the scorpion. Am J Physiol 1993; 264:C361-9.26.

[53] Deshane J, Garner CC, Sontheimer H. Chlorotoxin inhibits glioma cell invasion via matrix metalloproteinase-2. J Biol Chem 2003; 278: 4135-44.

[54] McFerrin MB, Sontheimer H. A role for ion channels in glioma cell invasion. Neuron Glia Biol 2005; 2: 1-11.

[55] Motsch J, Walther A, Bock M, Bottiger BW. Update in the prevention and treatment of deep vein thrombosis and pulmonary embolism. Curr Opin Anaesthesiol 2006; 19: 52-8.

[56] Craig AG, Norbert T, Griffin D, Hoeger C, Akhtar M, Schmidt K, et al. Contulakin-G, an O-glycosylated invertebrate neurotensin. J Biol. Chem 1999; 274:13752-9.

[57] Badio B, Daly JW. Epibatidine, a potent analgetic and nicotinic agonist. Mol Pharmacol 1994; 45:563-9.

[58] Bannon AW, Decker MW, Curzon P, Buckley ML, Kim DJ, Holladay MW, et al. ABT-594 [(R)-5-(2-azetidinylmethoxy)-2chloropyridine]: a novel, orally effective antinociceptive agent acting via neuronal nicotinic acetylcholine receptors: II. In vivo characterization. J Pharmacol Exp Ther 1998; 285: 787-94.

[59] Watters MR. Tropical marine neurotoxins: venoms to drugs. Semin Neurol 2005; 25:278-89.

[60] Kuphal S, Bauer R, Bosserhoff A-K. Integrin signaling in malignant melanoma. Cancer and Metastasis Rev 2005; 24:195-222.

[61] Clark EA, Trikha M, Markland FS, Brugge JS. Structurally distinct disintegrins contortrostatin and multisquamatin differentially regulate platelet tyrosine phosphorylation. J Biol Chem 1994; 269:21940-43.

[62] Trikha M, Rote WE, Manley PJ, Lucchesi BR, Markland FS. Purification and characterization of platelet aggregation inhibitors from snake venom. Thromb Res 1994; 73: 39-52.

[63] Trikha M, DeClerch YA, Markland FS. Contortrostatin, a snake venom disintegrin, inhibits beta 1 integrin-mediated human metastatic melanoma cell adhesion and blocks experimental metastasis. Cancer Res 1994; 54: 4993-8.

[64] Marsh NA. Diagnostic uses of snake venom. Haemostasis 2001; 31:211-7.

[65] Funk C, Gmur J, Herold R, Straub PW. Reptilase ${ }^{\circledR}-R-A$ new reagent in blood coagulation. Brit J Haematol 1971; 21: 43-52.

[66] Stocker K, Fischer H, Meier J. Practical application of the protein C activator Protac $®$ from Agkistrodon contortrix venom. Folia Haematol (Leipzig) 1988;115: 260-4.

[67] Read MS, Potter JY, Brinkhous KM. Venom coaggutinin for detection of von Willebrand factor activity in animal plasmas. J Lab Clin Med 1983; 101:74-82

[68] Tokunaga F, Nagasawa K, Tamura S, Miyata T, Iwanaga S, Kisiel W. The factor V-activating enxyme (RVV-V) from Russell's viper venom. Identification of isoproteins RVV-V alpha, -V beta, and -V gamma and their complete amino acid sequences. J Biol Chem 1988; 263:17471-81

[69] Tans G, Rosing J. Snake venom activators of factor X: an overview. Haemostasis 2001; 3-6:225-33.

[70] Morita T. Structures and functions of snake venom CLPs (C-type lectin-like proteins) with anticoagulant-, procoagulant-, and platelet-modulating activities. Toxicon 2005; 45:1099-114.

[71] Harvey AL. Recent studies on dendrotoxins and potassium ion channels. Gen Pharmacol 1997; 28: 7-12. 
[72] Grutter T, Le Novere N, Changeux JP. Rational understanding of nicotinic receptors drug binding. Curr Top Med Chem 2004; 4 : 645-50.

[73] Vita C, Roujestand C, Toma F, Menez A. Scorpion toxins as natural scaffolds for protein engineering. Proc Natl Acad Sci USA 1995; 92: 6404-8.
[74] Martin L, Stricher ML, Misse D, Sironi F, Pugniere M, Barthe P, et al. Rational design of a CD4 mimic that inhibits HIV-1 entry and exposes cryptic neutralization epitopes. Nat Biotechnol 2003; 21 : 71-6. 
Copyright of Current Pharmaceutical Design is the property of Bentham Science Publishers Ltd. and its content may not be copied or emailed to multiple sites or posted to a listserv without the copyright holder's express written permission. However, users may print, download, or email articles for individual use. 